\title{
MOTIF BERINTERAKSI IMIGRAN ILEGAL DENGAN MASYARAKAT KOTA PEKANBARU
}

\author{
Ringgo Eldapi Yozani \\ Jurusan Ilmu Komunikasi Fakultas Ilmu Sosial dan Ilmu Politik Universitas \\ Riau
}

email: ringgo.eldapi@lecturer.unri.ac.id

\begin{abstract}
Abstrak
Penelitian ini untuk mengetahui motif berinteraksi yang dilakukan imgran ilegal asal Afganistan dengan masyarakat Kota Pekanbaru. Teori yang digunakan dalam penelitian ini adalah Teori Fenomenologi dari Alfred Shutz. Schutz menyatakan bahwa dalam penelitian fenomenologi peneliti berusaha untuk menggali pemahaman individu seseorang dalam mengkonstruksi makna serta konsep penting dalam kerangka pemahaman kita terhadap dunia yang dibentuk dalam interaksi kita dengan orang lain. Analisis dalam penelitian ini menggunakan metode fenomenologi dari hasil wawancara dan observasi lapangan. Hasil dari penelitian ini adalah Motif yang dimiliki Imigran Ilegal asal Afganisthan berinteraksi dengan masyarakat adalah Motif Sosial, Motif Belajar serta Morif Hiburan. Motif sosial merupakan alasan yang dijadikan oleh imgran ilegal untuk berinteraksi dengan masyarakat, karena pada dasarnya sosialisasi merupakan kebutuhan dasar manusia, termasuk imigran ilegal. Motif belajar yakni ingin mengenal sesuatu yang baru baik itu tentang bahasa ataupun kebudayaan masyarakat setempat. Sedangkan motif hiburan untuk sekedar untuk membuang kejenuhan ataupun menyalurkan hobi seperti olahraga, ataupun berkeliling di temat-tempat keramaian.
\end{abstract}

Kata Kunci: Imigran Ilegal, Motif, Interaksi

\begin{abstract}
This research is to find out the motive for interacting by asylum seekers from Afghanistan with the people of Pekanbaru City. The theory used in this research is the Theory of Phenomenology from Alfred Shutz. Schutz states that in phenomenological research researchers try to explore one's individual understanding in constructing meaning and important concepts in the framework of our understanding of the world formed in our interactions with others. The analysis in this study uses the phenomenological method from the results of interviews and field observations. The results of this study are the Motives owned by Illegal Immigrants from Afganisthan interacting with the community are Social Motives, Learning Motives and Entertainment Morals. Social motives are the reasons used by asylum seekers to interact with the community, because basically socialization is a basic human need, including illegal immigrants. The motive for learning is to want to know something new both about the language or culture of the local community. While the motive for entertainment is simply to get rid of boredom or to channel hobbies like sports, or to go around in crowded places.
\end{abstract}

Key Words: Illegal Immigrants, Motives, Interactions 


\section{PENDAHULUAN}

Indonesia merupkan negara kepualauan terbesar di dunia yang terleta di Asia Tenggara. Indonesia dilalui garis khatulistiwa yang berada diantara daratan benua Asia dan Australia serta Samudra Hindia dan Samudra Pasifik. Indonesia memiliki lebih kurang 17.504 pulau. Dikarenakan kondisi geografis Indonesia yang besa dan terdiri dari beribu-ribu pulau tersebut membuat Indonesia banyak memiliki pintu masuk seperti bandara, pelabuhan. Selain itu juga, Indonesia yang memuliki garis pantai sepanjang 95.181 KM yang terletak pada posisi strategis yakni do jalur lalu lintas perdangan international, membuat Indonesia berpeluang besar untuk terjadinya tindak kejahatan Transnasional. Indonesia juga banyak dijadikan sebagai negara transit bagi para pengungsi dari negara konflik sebelum akhirnya mereka diterima di Negara ketiga. Hal tersebut tentunya akan dapat membuat ganggunan stabilitas kehidupan social, politik serta keamanan masyarakat.

Lembaga keimingriasi akan menjadi ujung tombak dalam pengawasan setiap orang yang akan kelar masuk dalam suatu wilayah negara. Akan tetapi, dalam praktiknya, imigrasi masi sering mengalami kecolongan dalam melakukan pengawasan tersebut, hal ini disebabkan karena besarnya wilayah Indonesia yang terdiri dari beribu pulau serta banyaknya pintu-pintu masuk yang tidak resmi menyebabkan Lembaga imigrasi kesulitan dalam melakukan pemantauan keluar masuknya orang asing ke wilayah Indonesia. Rumah Detensi Imigrasi yang selanjutnya disingkat RUDENIM adalah tempat sementara bagi orang yang berasal dari negara di luar Indonesia yang melanggar undang-undang keimigrasian dan menunggu proses kepulangan ke masing-masing negara asalnya. Rudenim di Kota Pekanbaru berfungsi melakukan pendetensian, pengisolasian, pemulangan dan deportasi imigran yang melanggar undang-undang keimigrasian.

Rudenim di kota Pekanbaru ini juga terdapat keunikan tersendiri yang berbeda dari rudenim-rudenim lain yang tersebar di kota-kota Indonesia. Rudenim di kota Pekanbaru adalah salah satu rudenim yang memperbolehkan para imgran ilegal keluar masuk rudenim dan bebas beraktifitas diluar rudenim. Menurut informasi yang didapat dari kepala bidang keamanan bahwasanya rudenim membuat aturan dan tata tertib bagi imgran ilegal yang ingin keluar-masuk dari rudenim. Para imgran ilegal diizinkan keluar untuk membeli kebutuhan mereka, seperti kebutuhan perlengkapan mandi dan lain-lain. Adapun peraturannya yang diberlakukan oleh Rudenim adalah memperbolehkan imgran ilegal keluar maksimal 3,5 jam, antara pukul 08:00 WIB s/d pukul 18:00 WIB. Jika lewat dari waktu yang ditentukan maka imgran ilegal yang melanggar akan dikenakan sanksi. Sanksi yang diberikan berupa pengurungan di dalam sel selama 7 hari, para imgran ilegal tidak diperbolehkan keluar selama 7 hari dan kartu tanda pengenal akan ditahan. Jam keluar dilakukan dengan sistem genap ganjil tergantung nomor dari registasi peserta. Para imgran ilegal yang memiliki nomor urut registrasi ganjil akan diberikan waktu keluar pada tanggal ganjil, begitu juga dengan nomor urut registrasi genap akan diberikan waktu keluar pada tanggal genap pula. Berikut kutipan wawancara penulis dengan kepala subseksi ketertiban Rudenim Pekanbaru:

"Rudenim Pekanbaru memiliki Tata tertib sendiri yang mengatur imgran ilegal untuk keluar dari Rudenim. Kita membuat aturan ini bukan tanpa sebab. Pertama, mereka bukan sebagai penjahat yang melakukan tindakan kriminal, kedua mereka adalah manusia biasa yang ingin juga bersosialisasi dan berinteraksi. Kalau mereka ingin kabur juga tidak bisa, karena mereka tidak memiliki dokumen resmi seperti 
Pasport dan Visa. Peraturan ini kita buat juga dengan aturan-aturan yang disepakati. Seperti satu hari hanya diperbolehkan keluar selama 3,5 jam dari jam 08.00 WIB - 18.00 WIB.".

Dengan diberlakukannya Standar Operasional Prosedur (SOP) diatas oleh pihak Rudenim Kota Pekanbaru, membuat peluang yang sangat besar untuk terjadinya interaksi antara Imgran ilegal dengan masyarakat di sekitar Rudenim di Kota Pekanbaru. Dari hasil pengamatan sementara yang peneliti lakukan, banyak para imgran ilegal yang beraktifitas di luar Rudenim seperti masyarakat Kota Pekanbaru pada umumnya. Pada sore hari para imgran ilegal bebas beraktifitas seperti berolahraga dan melakukan kegiatan lainnya.

Proses akulturasi yang terjadi antara imigran ilegal dengan masyarakat kota Pekanbaru melalui Komunikasi Lintas Budaya. Para imigran ilegal tersebut berusaha untuk beradaptasi dengan lingkungan sehingga merasa diterima dalam kelompok social masyarakat di Kota Pekanbaru. Oleh karena itu orang-orang Pekanbaru, para imgran ilegal juga memperoleh pola-pola budaya pribumi dari kegiatan komunikasi lintas budaya.

Penulis mengutip penelitian terdahulu dari Yoki Yusanto yang meneliti tentang Komunikasi lintas budaya orang Asli Papua (OAP) di Belanda. Pada penelitian ini Yoki mengungkapkan Motif Berkomunikasi Orang Asli Papua (OAP) di Belanda pada Konteks Identitas dan Bagaimana Orang Asli Papua (OAP) di Belanda dalam memaknai Papua (Yusanto, 2018). Selanjutnya penelitian yang dilakukan Rd. Nia Kania dengan Judul Komunikasi Lintas Budaya Diaspora Indonesia di Jerman Hasil penelitian Nia Kania menunjukan bahwa Diaspora Indonesia berorientasi dan mengkoordinasikan perilaku mereka dalam rangka mencapai fungsi social; memperoleh tujuan pribadi, dan yang sesuai dengan situasi dan harapan normative (Kurniawati, 2016).

Penelitian selanjutnya yang dilakukan Lubis dengan judul Komunikasi Antar budaya Etnis Tionghoa dan Pribumi di Kota Medan. Tujuan penelitian ini untuk mengetahui komunikasi antar budaya mepengaruhi pandangan dunia etnis Tionghoa dan pribumi di Kota Medan (Lubis, 2012). Terakhir riset yang dilakukan Anne McNevin, Antje Missbach, dan Deddy Mulyana yang dimuat dalam Jurnal International Political Sosiology pada tahun 2016 dengan judul "The Rasionalities of Migration Management: Control and Subversion in an Indonesia-Based Counter-Smuggling Campaign". Artikel ini membahas tentang sebuah kampanye kontra-penyelundupan yang didanai oleh Australia dan dikirim di Indonesia dari tahun 2009 sampai 2014 sebagai sebuah contoh terhadap rezim peraturan global yang dikenal sebagai Manajemen Migrasi (McNevin, Missbach, \& Mulyana, 2016).

Menjadi imigran ilegal bukanlah keputusan yang ingin diambil oleh setiap manusia, apalagi perjalanan tersebut dilakukan secara ilegal yang membuat diri mereka dipandang negatif dan dilabeli dengan identitas sebagai seorang imgran ilegal. Keputusan yang sangat berat untuk diambil ketika harus meninggalkan keluarga, teman, sahabat dan negara tercinta yang diakibatkan oleh kondisi negara yang tidak aman karena peperangan dan kondisi politik yang begejolak membuat para imgran ilegal untuk berpindah mencari kehidupan yang lebih baik lagi pastinya. Akan tetapi akibat gejolak tersebut membuat mereka melakukannya tanpa dengan surat-surat. Oleh karena itulah mereka disebut sebagai Imigran Ilegal dan Imgran ilegal. Status sebagai imigran ilegal di negara transit sebelum akhirnya sampai kenegara ketiga yang membedakan mereka dengan warga negara tempat mereka 
transit. Status sebagai imgran ilegal juga yang membedakan antara mereka yang masuk kedalam suatu wilayah negara secara resmi dengan menggunakan dokumen seperti pasport dan visa dan mereka yang masuk tanpa dokumen resmi.

Penelitian ini dilakukan untuk mengetahui motif berinteraksi yang dilakukan imgran ilegal asal Afganistan dengan masyarakat Kota Pekanbaru.

\section{KERANGKA TEORI}

Teori Fenomenologi. Menurut The Oxford English Dictionary, yang dimaksud dengan fenomenologi adalah (a) the science of phenomena as distinct from being (ontology), dan (b) division of any science which describe and classifies its phenomena. Fenomenologi merupakan ilmu yang mempelajari tentang fenomena yang dibedakan dari sesuatu yang akan menjadi atau sebuah disiplin ilmu yang mengklasifikasikan mengenai suatu fenomena atau studi mengenai fenomena. Fenomenologi yakni mempelajari fenomena yang tampak dan bagiaman penampakannya. (Kuswarno, 2009:1)

Pendekatan fenomenologi dari Alfred Schutz menyatakan bahwa realitas social dicirikan dengan subjektif dan duniawi. Schutz memandang dunia dari kehidupan sehari-hari yang merupakan sebuah realitas dari seseorang individu yang dikonstruksi sebagai sebuah intersubjektivitas. Perilaku manusia seacar social tidak dipandang secara subjektif saja, akan tetapi juga dipandang secara objektif yang berpedoman kepada komunitas dan makna yang dihasilkan secara bersama-sama oleh komunitas tersebut. Makna yang dilahirkan secara subjektif diperkuat oleh pengalaman yang di konsepsikan orang lain, sehingga menghasilkan banyak pengalaman yang pada akhirnya menghasilkan objektivitas dari sebuah ralitas.

Mempelajari Fenomenologi berarti bertujuan untuk mengetahui bagaimana sebuah realitas yang dialami dala, kesadara, fikiran serta tindakan seperti realitas tersebut memiliki nilai secara estetis. Fenomenologi berusaha mencari pemahaman bagaimana individu dapat mengkonstruksi sebuah makna serta konsep-konsep penting dalam kerangka intersbujektivitas. Intersubjektif merupakan sebuah pemahaman individu mengenai dunia yang dibentuk melalui hubungan dengan orang lain, walaupun terkadang makna yang dihasilkan dapat ditelusuri dalam sebuah tindakan, aktivitas dan karya yang kita lakukan, akan tetaoi tetap saja ada peran individu lain didalamnya. ((Kuswarno, 2009:2)

Dalam penelitian ini, teori fenomenologi digunakan untuk dapat menemukan dan mengali motif dari imigran illegal yang berasal dari Afganistan dalam berinteraksi dengan masyarakat Pekanbaru. Kemudian selanjutnya untuk menemukan serta menganalisis pengalaman kesadaran dan juga pengembangan dari interaksi yang dilakukan untuk beradaptasi dan mempertahankan hidup selama berada di Pekanbaru.

Interaksi Sosial. Sebagai makhluk social manusia tidak bisa tidak berinteraksi dengan manusia lainnya. Hal ini merupakan faktor yang membetuk pribadi seorang manusia. Oleh karena itu, manusia tidak akan dapat hidup tanpa bantuan manusia lainnya. Hal tersebut membuat manusia akan melakukan interkasi satu sama lainnya. Menurut Bonner (dalam Gerungan, 2004) mengatakan bahwa interaksi social adalah sebuah interaksi yang terjadi antara dua orang atau lebih dimana individu satu akan mempengaruhi atau memperbaiki kelakuan individu lainnya, atau sebaliknya. Ditinjau dari sudut psikologis, Newcomb (dalam Santoso, 
2010) mendefinisikan interaksi social merupakan peristiwa yang kompleks, tingkah laku yang berupa rangsangan serta reaksi keduanya dan mempunyai satu arti sebagai sebuah rangsangan dan yang lain sebagai reaksi. Pola Komunikasi dalam sebuah interaksi dilakukan dengan mandiri maupun secara bersama-sama dengan melibatkan lembaga lain (Trijupitasari \& Riauan, 2017).

Individu yang melakukan interaski social dengan individu ainnya bukan hanya karena individu tersebut sebagai makhluk social yang membutuhkan orang lain saja, akan tetapi interaksi social juga merupakan suatu keutuhan dasar dari setiap individu manusia. Menurut Schutz (dalam Sarwono, 2004) menjelaskan bahwa pada dasarnya setiap orang mengorientasikan dirinya terhadap orang lain dengan berbagai vara dan cara tersebut merupakan faktor utama yang akan mempengaruhi tingkah lakunya dalam melakukan houngan dengan orang lain. Schutz juga menyebutkan dalam teori FIRO (Fundamental Interpersonal Relation Orientation) bahwa kebutuhas dasar inf=divide dalam hubungan natar individu denagn individu lainnya terdiri dari tiga kebutuhan dasar, yakni inklusi, control dan afeksi. Inkusi merupakan kebutuhan untuk terliat dan termasuk dalam kelompok, control merupakan arah dan pedoman dalam berperilaku serta afeksi yang merupakan kebutuhan akan kasih sayang dan perhatian dari anggota kelompok lainnya.

Menurut Soekanto (2007) interaksi social tidak akan terjadi apabila tidak memenuhi dua syarat, yakni adanya kontak social dan adanya komunikasi. Kotak social merupakan suatu syaarat untuk terjadinya interaksi social. Kontak social dapat terjadi akibat adanya stimulus yang diberikan oleh seseorang kepada orang lain yang menghasilkan respon. Kontak social merupakan tahap awal terjadinya interaksi social. Setelah terjadinya kontak social maka tahap selanjutnya adalah terjalinnya komunikasi. Komunikasi merupakan keadaan dimana orang memberikan arti terhadap perilaku orang lain, perasaan-perasaan yang ingin disampikan yang kemudia akan direspon. Dengan demikian, dengan adanya komunikasi maka sijap dan perasaan dari suatu kelompok atau orang perorangan akan dapat diketahui oleh kelompok atau orang lain.

Motif. Menurut Engkus Kuswarno (2009:194), ada tiga kategori motif, yakni motif sebab yang menunjukan orientasi pada masa lalu, motif agar yang menunjukan orientasi pada masa kini, dan motif untuk menunjukan orientasi masa akan datang. Penjelasan tersebut di perkuat dengan pendapat dari Schulz, setiap perilaku memiliki motif yang secara psikologis akan menentukan arah perilaku, apakah perilaku tersebut berdasarkan motif "sebab" (because motive), atau motif "supaya" (in order to motive) tergantung dari konteks untuk masing-masing individu. Tingkah laku yang tampak merupakan sebuah gejala (noema) dari apa yang menjadi persepsi dan motivasi individu tersebut. (Utami, $2015:$ 19).

Menurut Gerungan didalam bukunya Psikologi Sosial (1996:194), Motif adalah yang meliputi semua penggerak. Dorongan serta lasarn yang terjadi di dalam diri individu manusia menyebabkan dia melakukan suatu tindakan terntentu. Semua tingkah laku dari individu manusia pada dasarnya memiliki sebuah motif. Tingkah laku secara reflex yang berlangsung secara otomatis memiliki maksud dan tujuan tentenut meskipun sebenarnya maksud tersebut tidak senantiasa sadar bagi individu manusia. Menurut Max Weber dan C. Wright Mills, motif adalah penjelasan secara verbal perilaku, merasionalisasikan perbuatan tertentu atau perbuatan orang lain. (Syam, 2013). 
Motif merupakan alasan manusia untuk menentukan dirinya. Penyebab adalah alasan terjadinya di luar kemauan manusia. Karena manusia adalah makhluk berasio dan akibatnya akan bertindak menurut motif-motif, maka sering kali tingkah lakunya memperlihatkan pola-pola yang tetap. (Berten, 2007:123)

\section{METODE PENELITIAN}

Penelitian tentang Motif Berinteraksi Imigran Ilegal dengan Masyarakat Kota Pekanbaru ini menggunakan paradigma Interpretif/ Konstruktivis karena peneliti ingin melihat dari sudut pandangan imigran ilegal sebagai subjek yang diteliti tentang bagaimana motif berinteraksi yang dilakukan oleh imigran ilegal dengan masyarakat Pekanbaru. Dalam peneliltian ini, penulis menggunakan metode kualitatif dengan pendekatan Fenomenologi. Pendekatan Fenomenologi memiliki tujuan untuk mengetahui sebuah fenomena dari sudut pandang individu yang mengalaminya secara langsung atau berkaitan dengan sifat-sifat alami manusia, dan makna yang ditempelkan kepadanya. Peneliti berpikir metode ini sangat tepat menjadi cara yang dapat menguraikan permasalahan pada penelitian Motif berinteraksi imigran illegal asal Afganistan dengan Masyarakat Kota Pekanbaru. Titchen dan Hobson dalam (Barnawi \& Darojat, 2018) menjelesakan fenomenologi sebagai sebuh ilmu tentang kehidupan manusia yang menjalani kesehariannya dalam konteks social tempat fenomena tersebut terjadii berdasarkan perpsektif individu yang terlibat langsung dalam sebuah pengalaman tersebut. Fenomena dapat diteliti melalui eksplorasi pengetahuan akses kesadarannya dan secara tidak langsung melalui investigasi terhadap individu yang langsung terlibat lewat pandangan serta pengaaman yang memiliki latar belakang makna yang sama. (Barnawi \& Darojat, 2018).

Teknik pemilihan informan adalah Teknik purposive, yaitu imigran illegal yangberada di rumah detensi imigrasi Kota Pekanbaru yang sudah menetap di selama satu tahun atau lebih serta telah bisa berbahasa Indonesia baik secara aktif maupun pasif. Penulis melakukan wawancara mendalam terhadap 11 orang imgran ilegal dari berbagai negara yang menghubi Rudenim Kota Pekanbaru. 11 orang tersebut sudah memenuhi kriteria yang telah penulis jelaskan diatas. Selain itu juga, penulis juga melakukan wawancara kepada pimpinan dan petugas Rudenim serta kepada masyarakat sekitar dimana para imgran ilegal tersebut beaktivitas dan berinteraksi satu sama lainnya. Sedangkan teknikpengumpulan data yang penulis gunakan dalam penelitian ini adalah dengan wawancara mendalam, observasi, serta dokumetasi.

\section{PEMBAHASAN}

Kebutuhan akan bersosialisasi tersebut juga dirasakan bagi para imgran ilegal yang menghuni Rumah Detensi Imigrasi di Kota Pekanbaru. Mereka merasa sangat senang berada di Rudenim Kota pekanbaru dikarenakan adanya kebijakan dari Rudenim yang memperbolehkan mereka keluar dari Rudenim dengan batasan waktu yang telah ditetapkan dalam setiap harinya. Kebijakan tersebut yang tidak mereka dapatkan ketika mereka berada di rudenim kota lainnya. Atas dasar kebijakan tersebut juga, membuka peluang yang besar serta dimanfaatkan oleh para imgran ilegal untuk berinteraksi dengan masyarakat di Kota Pekanbaru. Para imgran ilegal sangat senang sekali dapat melakukan interaksi dengan masyarakat, ditambah lagi masyarakat Pekanbaru yang ramah-ramah sehingga para imgran ilegal tersebut dapat betah, tinggal dan berinteraksi dengan masyarakat. Meskipun dengan 
keterbatasan bahasa dalam berkomunikasi akan tetapi tidak menyurutkan niat para mereka untuk tidak berinteraksi dengan masyarakat. Seperti yang dikatakan NA dalam kutipan wawancara sebagai berikut:

"Sebelum menghuni Rudenim Pekanbaru, saya berada di Jakarta dan Bogor. Di Jakarta dan Bogor tidak enak, kami di kurung di dalam Sel, tidak diperbolehkan keluar. Selain itu juga karena kami takut kena tangkap. Setelah urusan registrasi selesai, saya balik ke Rudenim Pekanbaru. Saya merasa senang berada di Rudenim Pekanbaru karena memperbolehkan para deteni untuk keluar Rudenim dengan batasan waktu. Hal tersebut yang membuat saya bisa berinteraksi dengan masyarakat, dan membuat saya banyak teman di Pekanabaru. Anda bisa bayangkan kalau kami tidak boleh keluar, hanya berada di dalam kamar dengan waktu yang tak tentu, itu sangat membosankan."

Seperti yang diakatakan NA, kebijakan Rudenim Pekanbaru yang memperbolehkan para imgran ilegal untuk keluar rudenim dan berinteraksi dengan masyarakat mendapat sambutan yang positif dari imgran ilegal sendiri. Banyak dari mereka yang memanfaatkan kesempatan tersebut, untuk berinteraksi dengan masyarakat. Berdasarkan penelitian yang peneliti lakukan di lapangan, ada beberapa motif bagi imgran ilegal untuk berinteraksi dengan masyarakat kota pekanbaru. Motif sosial, motif ekonomi, motif pendidikan, serta motif hiburan yang membuat imgran ilegal tersebut berinteraksi dengan masyarakat di Kota Pekanbaru.

Motif Sosial. Manusia sebagai makhluk sosial tidak bisa tidak berinterkasi dengan manusia lainnya. Semua manusia dimuka bumi ini memiliki ketrgantungan satu sama dengan lainnya. Begitu juga halnya dengan para imgran ilegal yang menghuni Rudenim Kota pekanbaru. Ruang lingkup sosial baru adalah ketika para imgran ilegal harus menghapai kenyataan bahwa mereka hidup dan berada di negara yang bukan tanah kelahirannya. Hidup dinegara yang bukan negara kelahirannya membuat para imgran ilegal tunduk dan taat dan patuh terhadap aturan yang berlaku di negara tersebut.

Para imgran ilegal yang berada di rudenim Kota Pekanbaru ini tidak akan bisa melepaskan diri dari interaksi dengan orang lain. Baik itu interaksi antara sesama imgran ilegaln maupun antara imgran ilegal dengan masyarakat. Untuk memenuhi kebutuhan sosialnya dan mendapatkan kepuasan batin dalam berinteraksi, mengharuskan para imgran ilegal untuk mengajak masyarakat berkomunikasi.

Informan yang peneliti temui, memiliki motif yang berebeda-beda pula ketika memutuskan untuk berinterkasi dengan masyarakat. Peneliti memberi nama motif sosial bagi para imgran ilegal yang ingin berinteraksi dan bersosialisasi dengan masyarakat. Motif ini menjelaskan bahwa manusia memerlukan bantuan orang lain untuk memenuhi kebutuhan hidupnya. Motif ingin bersosialisasi merupakan motif masa kini yang dimiliki oleh imgran ilegal. Mereka menyatakan bahwa, ketika mereka tidak diperbolehkan keluar dan berinteraksi dengan masyarakat, maka mereka akan merasakan kebosanan yang sangat besar. Berikut kutipan wawancara denga GSR:

"Ketika aku sedang berjalan di jalan Ahmad Yani dekat hotel Satria. Sorenya, aku pergi ke Masjid Annur untuk berlari. Beberapa mahasiswa yang lebih tahu Bahasa Inggris, bertanya padaku "Kamu berasal darimana?" "Siapa namamu?" "Berapa umurmu?". Aku berusaha menjelaskan kepada mereka, mengapa aku tinggal disini. Mereka bisa mengerti, ini merupakan tujuanku. Jika kamu datang ke Afganistan, ini 
merupakan pertanyaan dariku. Jadi mereka hanya menyakan beberapa pertanyaan sederhana. Hal pertama dan pasti, ini merupakan pengalamanku tinggal di Pekanbaru, aku menjawab pertanyaan orang Indonesia dengan baik karena mereka juga orang yang sangat baik, dan sangat ramah. Mereka berusaha untuk berbicara dengan orang asing."

Kebutuhan akan bersosialisasi juga dirasakan oleh GSR dan para imgran ilegal lainnya. Berada di tempat yang baru dan tidak dikenal, imgran ilegal ini perlu uintuk melakukan penyesuaian diri dalam rangka bertahan hidup. GSR menyatakan diatas bahwa untuk bersosialisasi dengan masyarakat Pekanbaru adalah satu kebutuhan yang harus dipenuhi. Keramahan masyarakat kota Pekanbaru, membuat GSR dengan mudah untuk berososialisasi dengan masyarakat.

Motif Belajar. Ingin mengenal sesuatu yang baru adalah salah satu sifat dasr dari manusia. Manusia memiliki rasa keingintahuan, dan ingin mencoba sesuatu yang baru, apalagi ketika kita berada di suatu lingkungan yang baru pula. Begitu pula halnya dengan para imgran ilegal yang menghubi di Rudenim Kota Pekanbaru. Berada di lingkungan yang baru yang memiliki perbedaan latar belakang budaya tentunya membuat para imgran ilegal ingin belajar dan memahami kebudayaan setempat dalam hal ini adalah kebudayaan di Kota Pekanbaru.

Imgran ilegal yang menghuni rudenim Pekanbaru banyak melakukan proses pembelajaran, terurama terdahap budaya masyarakat setempat. Proses belajar ini terjadi ketika para imgran ilegal yang berada di rudenim Pekanbaru mengalami ketidakmampuan dalam berkomunikasi dengan masyarakat. Hal tersebut membuat para imgran ilegal ingin belajar tentang kebudayaan dan bahasa yang digunakan masyarakat Pekanbaru.

Imgran ilegal juga memanfaatkan momen diberikannya izin keluar dari Rudenim untuk berinteraksi dengan masyarakat ini adalah untuk mempelajari kebudayaan masyarakat setempat. Kebudayaan yang dipelajari mulai dari cara berpakaian, logat, artikulsi bahasa, adat istiadat, tradisi perkawinan, bahkan para imgran ilegal sendiri sudah bisa berbahasa daerah yakni bahasa minang. Seperti penjelasan dari beberapa informan peneliti dalam kutipan wawancara dengan informan MJA, Mn, dan AA sebagai berikut:

"Banyak orang pekanbaru melihatku ketika aku berada diluar, mungkin karena secara fisik kita berbeda. Aku tidak tahu apa yang mereka fikirkan tentangku. Positif atau negatif. Aku rasa, tapi ini bisa saja salah. Orang Indonesia, kebanyakan dari mereka tidak bisa berbahasa Inggris. Beberapa dari mereka, mereka memperhatikan kita, tapi mereka tidak bisa berbahasa Inggris, aku tidak tahu kenapa. Akan tetapi ini membuatku untuk lebih bisa tertantang untuk memplejari bahasa mereka, atau setidak bahasa inggris yang pas-pasan."

Dari hasil wawancara penulis dengan informan diatas yang dikutip dalam hasil wawancara diatas, dapat dimaknai bawah motif belajar bahasa dan kebudayaan adalah motif mereka berinteraksi dengan masyarakat. Motif belajar dibagi menjadi ingin belajar bahasa Indonesia sebagai bahasa masyarakat setempat ketika mereka masi beradaa di tempat penampungan, dan belajar bahasa inggris ketika mereka berada di negar ketiga nantinya. Selain juga ingin belajar kebiasaan serta kebudayaan dari masyarakat Pekanbaru, membuat para imgran ilegal sangat antusias merupakan salah satu motif untuk berinteraksi dengan masyarakat. 
Motif Hiburan. Kebutuhan akan mendaptkan hiburan ataupun hanya sekedar menyalurkan hobi membuat menjadi faktor yang membuat para imgran ilegal ini berinterkasi dengan masyarakat. Peneliti melihat kondisi di lapangan bahwa para imgran ilegal yang berada di Rudenim Pekanbaru memiliki alasan ini untuk berinterkasi dengan masyarakat. Peneliti mengidentifikasi kebutuhan ini menjadi Motif Hiburan. Motif hiburan adalah motif yang dimiliki oleh imgran ilegal untuk melakukan interaksi dengan masyarakay agar merasa tidak bosa, bisa menyalurkan hobby, bisa berolargaha dan lain sebagainya. Hal ini agra tidak terjadi kejenuhan bagi para imgran ilegal selama berada di rudenim yang mereka sendiri tidak tahu akan sampai kapan berada disana.

Berdasarkan hasil pengamatan yang penulis lakukan di sekitar lingkungan rudenim dan bahkan di pusat-pusat keramaian di Kota Pekanbaru, terlihat bahwa para imgran ilegal banyak bebas berkeliaran melakukan aktifitas dan bahkan menyalurkan hobi mereka. Ada sebagian dari mereka yang berolahraga, menyalurkan hobi, berbelanja dan bercengkrama di tempat makan di pusat-pusat perbelajaan di Kota Pekanbaru.

GSR seorang imgran ilegal asal Afghanistan mengatakan memanfaatkan waktu yang diberi oleh pihak rudenim untuk menyalurkan hobinya, yakni berolahrga dan berrcengkrama dengan beberapa temannya di pusat perbelanjaan kota Pekanbaru. Pagi hari dimanfaatkan GSR untuk berolahraga Joging, dan Sore hari dimanfaatkan untuk berolahraga Volly. Pada hari-hari tertentu dia juga menyalurkan hobinya untuk bermain futsal dan berolahraga renang. GSR sendiri memiliki temanteman bermain futsal dari masyarakat dan sering bertemu masyarakat setempat juga ketika melakukan oleharga berenang. Bahkan terkadang GSR memanfaatkan waktunya untuk sekedar menyalurkan hobi membacanya untuk pergi ke toko buku. Berikut hasil wawancara dengan GSR seperti kutipan di bawah ini:

"Saya sering berolahraga, setiap pagi olahraga Joging, dan pada sore hari kami bermain Volly dengan petugas rudenim. Selain itu juga pada waktu tertentu saya bermain futsal di jalan paus, da berenang di Kolam Renang Aras. Beberapa dari kami senang membaca buku. Gramedia. Beberapa orang pergi ke Perpustakaan Gramedia (Toko Buku Gramedia). Atau contoh lain, beberapa dari mereka memiliki teman untuk meningkatkan kemampuan berbahasa Inggris mereka. Mereka berbicara serta membaca."

Dalam penuturan dari GSR diatas terlihat bahwa motif hiburan merupakan salah satu motif yang dimiliki oleh imgran ilegal dalam berinterkasi dengan masyarakat. Hanya sekedar menyalurkan hobi, ataupun bercengrkrama dengan teman di tempat-tempat keramaian sudah membuat kesenangan tersendiri bagi para imgran ilegal saat berada di negara transit ini. Bahkan menurit pengakuan Shaki juga banyak para imgran ilegal yang bebas berkeliaran di pusat perbelanjaan dan menyalurkan hobi untuk berbelanja.

Imigran ilegal adalah aktor yang melakukan tindakan sosial yakni yang melakukan migrasi secara ilegal. Berdasarkan pemikiran Schutz, maka imgran ilegal adalah sebagai aktor yang memiliki salah satu dari dua motif. Motif yang berorientasi pada masa lalu (because-motive) yaitu motif ketika para imgran ilegal memutuskan untuk melakukan interaksi kepada masyarakat. Sedangkan motif yang berorinetsi 
masa yang akan datang (in order to motive) yaitu motif yang diharapkan oleh imigran illegal setelah mereka melakukan interaksi dengan masyarakat.

Motif berinteraksi seperti yang dijelaskan diatas menurut pendapat peneliti merupakan aktifitas kehidupan sehari-hari yang dilakukan oleh manusia, artinya bagi imgran ilegalpun aktivitas tersebut merupakan suatu kebutuhan bagi mereka. Peneliti melakukan sebuah konfirmasi pada teori Fenomenologi dari Peter Berger, yang menekankan pada interaksi antar manusia. Focus perhatiannya adalah pengetahuan umum yang berkaitan dengan kehidupan sehari-sehari serta bagaiaman cara masyarakat mengorganisasikan pengalaman dan dunia social mereka. Berger juga menekankan bahwa actor memiliki makna yang subjektif, rasional serta bebas. Aktivitas inddividu manusia dapat dipahami sebagai sesuatu yang memiliki makan baginya didalam masyarakat. Oleh karena itu segala sesuatu aktivitas yang diakukan harus diinterpertasikan. (Kuswarno, 2009 : 20).

Dalam menjalankan kehidupan di Rudenim Kota Pekabaru, banyak aktifitas dan kegiatan yang dilakukan oleh imgran ilegal untuk menghindari kebosanan dan kejenuhan. Menunggu sesuatu yang belum pasti kapan datangnya, membuat para imgran ilegal keluar dari Rudenim dan melakukan interaksi dengan masyarakat Kota Pekanbaru. Berdasarkan hasil wawancara yang penulis lakukan dengan informan, penulis mendapatkan tiga motif imgran ilegal dalam melakukan interaksi dengan masyarakat Kota Pekanbaru. Motif sosial, motif belajar, dan motif hiburan merupakan alasan dari informan yang penelit wawancarai. Ketiga motif diatas menurut pendapat peneliti merupakan aktifitas kehidupan sehari-hari yang dilakukan oleh manusia, artinya bagi imgran ilegalpun aktivitas tersebut merupakan suatu kebutuhan bagi mereka.

Eksternalisasi yang terjadi adalah dalam melihat realitas yang terjadi di lingkungan sosial baru, di mana kebutuhan manusia adalah untuk dapat berkomunikasi dalam lingkungan sosial. Sadar akan sebagai masyarakat minoritas yang berada diantara masyarakat mayoritas adalah merupakan realitas yang dihadapi oleh imgran ilegal di Rudenim Kota Pekanbaru. Realitas ini tidak berdiri sendiri, akan tetapi merupaka sebuah peristiwa yang terjadi akibat adanya kesadaran dalam diri imgran ilegal untuk melakukan sebuah perubahan hidup selama berada di Rudenim Kota Pekanbaru.

\section{KESIMPULAN}

Berdasarkan hasil penelitian dan pembahasan yang telah dipaparkan diatas, maka dapat disimpulkan bahwa motif berinteraksi yang dilakukan oleh Imgran ilegal dengan Masyarakat Pekanbaru yang berada di Rudenim adalah motif ingin sosial, motif belajar, serta motif hiburan. Hal ini merupakan dampak dari sebuah aturan yang memperbolehkan para imgran ilegal untuk keluar rudenim, sehingga membuat perluang yang besar untuk terjadinya interaksi antara imgran ilegal dengan masyarakat Kota Pekanbaru.

\section{DAFTAR PUSTAKA}

Bajari, Atwar, 2015. Metode Penelitian Komunikasi. Bandung: Simbiosa Rekatama Media. 
Cushner, Kenneth \& Ricahrd W. Brislin. 1996. Intercultural Interactions A Practical Guide. 2nd. California: Sage Publications.

Devito, Joseph A. 1992. Komunikasi Antarmanusia. Edisi Kelima. Jakarta: Profesional Books.

Effendy, Onong Uchjana. 2003. Ilmu Komunikasi Teori dan Praktek. Cetakan kesembilanbelas. Bandung: PT Remaja Rosdakarya

Griffin, EM. 2006. A First Look at Communication Theory. 6th edt. NY: McGraw Hill

Gudykunts, William B \& Bella Mody. Edt. Handbook of International and Cultural Communication. 2nd edt. USA: Sage Publications.

Kuswarno, Engkus. 2009. Metode Penelitian Komunikasi, Fenomenologi, Konsepsi, Pedoman dan Contoh Penelitiannya. Bandung: Widya Padjadjaran.

Littlejohn, Stephen W. Karen A. Foss, editors. 2009. Encyclopedia of Communication Theory. USA: Sage Publication.

Moleong, Dr. Lexy J. 2002. Metodologi Penelitian Kualitatif. Bandung : PT Remaja Rosdakarya.

Mulyana, Deddy. 2004. Ilmu Komunikasi: Suatu Pengantar. Bandung: PT. Remaja Rosdakarya.

2012. Cultures and Communication, An Indonesian Scholar's Perspective. Bandung: PT. Remaja Rosdakarya

Rahman, Mustafa Abd. 2002. Afganistan di Tengah Arus Perubahan. Jakarta: PT Kompas Media Nusantara

Samovar, Larry A, Richard E. Porter, Edwin R. Mc Daniel. 2010. Komunikasi Lintas Budaya: Communication between cultures. Jakarta: Salemba Humanika.

Soeprapto, Enny. 1982 Beberapa Aspek Hukum Masalah Pengungsi, Jakarta: UNHCR.

Trijupitasari, R., \& Riauan, M. A. I. (2017). Pola Komunikasi Komisi Penanggulangan AIDS (KPA) Kota Pekanbaru Dalam Mensosialisasikan Bahaya HIV dan AIDS Kepada Penjaja Sex dan Gay. Jurnal Medium.

Wagiman. 2012. Hukum Pengungsi International. Jakarta: Sinar Grafika.

Warikoo, K. 2007. Afghanistan Issues and Perspectives. New Delhi: Pentagon Press.

West, Richard, Lynn H. Turner. 2010. Introducing Communication Theory: Analysis and Application 3rd ed. Jakarta: Salemba Humanika.

Widyosiswoyo, Supartono. 2004. Ilmu Budaya Dasar: Edisi revisi 2004. Bogor: Ghalia Indonesia. 